\title{
AL-GHAZĀLI''S CONTRIBUTION TO THE SUNNĪ JURISTIC DISCOURSES ON APOSTASY
}

\author{
Ahmad Atif Ahmad \\ UNIVERSITY OF CALIFORNIA, SANTA BARBARA
}

\begin{abstract}
The significance of al-Ghazālī (d. 1111) in Islamic intellectual history cannot be disputed, but his influence on the Sunnī juristic discourse on apostasy may be exaggerated. Ghazālî̀'s contribution to the Sunnī juristic discourse on apostasy includes a trilogy: first, an attack on the philosophers known as Tahäfut al-falāsifa (The Incoherence of the Philosophers) in which he accuses them of unbelief if they believe in the eternity of the world or God's ignorance of the particular events of the world or deny bodily resurrection in the world to come. Second is an attack on con-

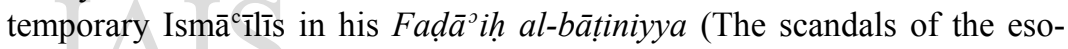
teric factions)where he holds their leaders to be infidels in addition to being a source of sedition. Third comes an attempt at providing a conceptual distinction between doctrinal heresy and apostasy while equating the concept of zandaqa with apostasy in his Fayșal al-tafriqa bayn al-islām wa-l-zandaqa (The distinction between Islam and zandaqa/unbelief). The Sunnī juristic discourse on apostasy was neither influenced by Ghazālī’s attempt to provide a decisive conceptual distinction between apostasy and doctrinal heresy nor by his equating of zandaqa and apostasy. Sunnī jurists referred to examples of apostasy that Ghazāli provided but did not seem to agree with his ambition of resolving the question of apostasy and distinguishing it from heresy once and for all, which left deciding who is an apostate in specific cases a matter of judicial discretion.
\end{abstract}

\section{The problem in a wider context}

It has been assumed that the designated punishment for apostasy in Sunnī Islamic law, which is death, has not been applied to individual alleged apostates frequently, even at times of factional and political tensions and at times of the spread of philosophical and esoteric ideas like those Ghazāli attacks in his Tahäfut al-falāsifa (The Incoherence of the Philosophers) and Fadā ih al-battiniyya (The scandals of the esoteric factions). One way of reconciling the existence of the punishment of apostasy and its rare application is to assume that the declared punishment was meant to be a theoretical deterrence, while only other, minor punishments may have occasionally been enforced on heretics and 
alleged apostates. ${ }^{1}$ Some scholars have proposed that part of the solution to the problem may be sought by investigating changes in the concept of apostasy in Islamic juristic literature. ${ }^{2}$ Based on the comparison of two views on what apostasy is, the punishment of the zindī $q$ (defined as a secret apostate) would be acceptable under Ghazālī's concept of apostasy in the eastern parts of the Muslim Empire, while Shäfici ${ }^{1}$ (d. 820) would have exonerated the zanādiqa as long as they professed to be Muslims.

It is not clear in this analysis whether Muslim jurists have ever distinguished between a punishment for apostasy that applies to 'individuals' and a punishment through 'war' that applies to rebellious apostates. Further, much textual evidence tends to support the assumption that the secret apostates punished under Ghazâlī's concept of apostasy would have been punished by death without being considered apostates before he formulated his definitions of apostasy, and that these same 'secret apostates' were seen as 'original unbelievers' by most jurists before and after Ghazālī wrote his treatises on the subject. For example, more than three centuries before Ghazālī, Ibn al-Mājishūn (d. 781) proposed that the zindi $q$ should be punished by death without stating that the zindi $q$ was an apostate, ${ }^{3}$ and, in the majority of Sunnī juristic literature, the zindī $q$ would be considered an 'original non-Muslim' rather than an apostate (since an apostate must be somebody with proven history of being a Muslim and having converted from Islam, while the zindīq's Islam is in question from the beginning). ${ }^{4}$ The assumption that any stability in the definition of apostasy was achieved is contradicted by a persistence of a measure of elasticity in the juristic discussion of the con-

${ }^{1}$ For the history of this problem, see Frank Griffel, 'Toleration and Exclusion: Al-Shāfíc'̄ and al-Ghazālī on the Treatment of Apostates', Bulletin of the School of Oriental and African Studies 64/3 (2001): 341-42.

2 Ibid., 342-54.

3 al-Hatțāb, Mawāhib al-Jalīl li-sharh Mukhtașar Khal̄̄l (Cairo, 1910), 6: 279. This is a six volume commentary by Muhammad ibn Muhammad ibn ${ }^{\mathrm{c}} \mathrm{Abd}$ al-Raḥmān al-Maghribī al-Ruc aynī known as al-Ḥațtāb on Khalīl ibn Ishāa alJundī’s (d. 1365) manual/summary on Mālikī Law. This commentary is published with other commentaries on the same legal manual (see also the next note), and reprints of this publication that appeared in subsequent years in Beirut and other cities.

4 al-Mawwāq (d. 1492), al-Tāj wa-l-iklīl li-Mukhtașar Khalīl (Cairo, 1910), 6: 279. This is another commentary on Khalil's Mukhtașar (or summary of Mālikī Law) authored by Muḥammad ibn Yūsuf al-'Abdarī, known as alMawwāq, published on the margins of al-Hatțāb's commentary (see note 3). 
cept, which does not seem to have bothered Sunnī Muslim jurists. Old concepts of apostasy survived despite the availability of new concepts, and the new concepts of apostasy were debated and tended to be appropriated or partially accepted by later generations of jurists. The problem then persists: how can one explain the variance between a theoretical punishment for apostasy and a 'shy' application of that punishment over the course of Islamic history?

This article mainly reassesses Ghazâlī's contribution to the Islamic juristic discourses on apostasy, especially the implication that an evolution of the concept of apostasy may have taken place after his attacks on the philosophers and the Isma $\bar{a}^{c} \overline{1}$ ìs. In addition, the article also provides possible answers to the question of the ostensible discrepancy between the theoretical condemnation of apostates and the rare application of the punishment of apostasy to individuals.

Was collective apostasy punished by war in the seventh century?

The wars of the seventh century under Abū Bakr (r. 632-34), which later came to be known as the apostasy wars, were fought mostly with Arab tribes who had not embraced Islam before the Prophet Muhammad's death in the year $632 . .^{5}$ Despite reports that he may have referred to these rebels' failure to pay the zakāh ('alms'), which they paid to the Prophet, Abu Bakr himself did not use the language of apostasy (ridda, literally 'reverting') to refer to these rebels he sent his armies to pacify. ${ }^{6}$ Abu Bakr is reported to have given three options (emphasized below by the author) to these 'rebels':

When you encounter the enemy among the unbelievers, God willing, call upon them to choose from one of three options. If they accept this, then accept their position and do not attack them. Call upon them to embrace Islam. If they accept that, then accept their embracing of Islam and do not attack them. Then offer them the option to move from their houses to the houses of the emigrants (i.e., join the community of the Prophet's Companions). ${ }^{7}$ If they accept this,

\footnotetext{
${ }^{5}$ M. Lecker, 'al-Ridda', Encyclopaedia of Islam (2nd edition; Leiden: Brill, 2000), Supplement, 12: 692-95. Henceforth $E I^{2}$.

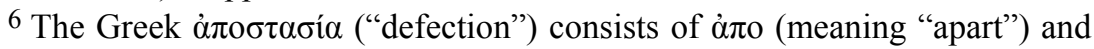

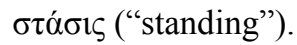

${ }^{7}$ Before the Prophet's conquest of Mecca in 630, the option of joining the Muslim community was given in armed conflict, since the Muslim community enjoyed a limited territorial sovereignty in Madīna. This situation seemed to have been repeated only during the reign of Abū Bakr. After the latter secured most of Arabia as a Muslim land and Muslim land was bound only to expand, the requirement to join the Muslim community became unnecessary.
} 
then tell them they are equal with the emigrants [the Companions who emigrated with the Prophet from Mecca to Madina]; they have the same rights and duties as these emigrants do. If they embrace Islam and choose to remain where they are, then tell them that they are equal with Muslim Bedouin: God's law applies to them, and they do not deserve any of the spoils of war unless they join the army. If they refuse to embrace Islam, then call on them to make a tax payment (jizya). If they accept, then accept that from them and do not attack them. If they refuse, then seek God's aid against them and fight them, with God's permission". 8

These reports may indeed have come from a late date, since they smack of the complex theory developed in Islamic law about the 'three options' given to enemies at war: conversion, jizya payment, or war. But what we can be sure of is that a doctrine of declaring war on apostates could not have developed at that early time. True, some of the tribes Abū Bakr fought (especially those Arabs of Najd) had signed treaties with the Prophet, accepting his authority and the rules of Islam. ${ }^{9}$ These can be called apostates if apostasy is understood to be a rejection of Islam after accepting it initially. Later jurists would consider the refusal to pay alms on the part of all of Abū Bakr's enemies a rejection of a basic religious duty, which amounts to a rejection of the doctrinal basis of that basic, necessarily known duty ( $\mathrm{ma}^{c} l \bar{u} m$ min al-dìn bi-l-darūra), but we have no evidence that this theory was developed at the time of the so-called apostasy wars. Even later jurists could not identify with any certainty these basic or necessarily known doctrines, the denial of which would make somebody an unbeliever.

This is not to say that no jurists relied on Abū Bakr's wars against Arabian tribes as a source for a law against collective apostasy. Shāfic ${ }^{\mathrm{i}}$ jurists believed that collective apostasy should be punished by war. ${ }^{10}$ It was likewise held that attacking apostate-rebels, whether these are in a land adjacent to Muslim lands or distant from them, takes priority over

\footnotetext{
${ }^{8}$ Muhammad Rawwās Qal ${ }^{c}$ ajī, Mawsū $\bar{c}^{c}$ at fiqh Abī Bakr al-Siddīq (Damascus: Dār al-Fikr, 1983), 88, citing Bayhaqī’s Sunan, 9: 85.

${ }^{9}$ For a summary of the problem of the variance between the Qur ${ }^{\top} \bar{n} n$ 's attitude about apostasy (which emphasized otherworldly punishment for apostasy) and the statements attributed to the Prophet about punishing apostates in this world, see Wael Hallaq, 'Apostasy,' in Encyclopedia of the Qur'ān, ed. Jane D. McAullife (Leiden: Brill, 2001), 1: 119-22, esp. 122.

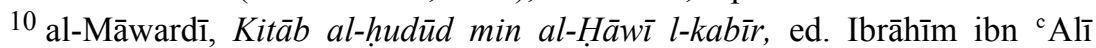
Șanduqjī, (Beirut, 1995), 2: 1077. This work is a 2 volume extract from alMāwardī’s al-Hāwwī.
} 
engaging non-Muslims in war. ${ }^{11}$ Shāfi ${ }^{c} \overline{1}$ argued that apostate-rebels are similar to unbelievers in certain respects, which distinguish them from Muslim rebels (bughāh). First, they can be attacked even if they retreat from the battle scene, while Muslim rebels can be attacked only if they attack Muslim armies. Second, using fire against the apostates is permissible, while in the war against Muslim rebels, fire cannot be used. Third, apostate captives can be killed, while this cannot be accepted in the case of Muslim rebels. Fourth, apostates' property can be confiscated by the Muslim authorities, while the property of Muslim rebels remains protected. But Shāfi ${ }^{c} \overline{1}$ also equated apostate-rebels with Muslim rebels in ways that distinguish them from non-Muslim enemies of Muslim armies. First, a peace treaty with the apostates cannot be concluded unless they return to Islam, while such a treaty with non-Muslim armies is acceptable. Second, jizya payment is acceptable only from non-Muslims, while an agreement with the apostates cannot be concluded based on their payment of jizya. Third, the apostates cannot be enslaved, while nonMuslims can be enslaved. Fourth, the property of the apostates cannot be appropriated, while this is allowed with non-Muslim enemies. ${ }^{12}$ Disagreement has arisen as to what Shāfi ${ }^{c} \overline{1}$ held about whether apostates or Muslim rebels should compensate for whatever they destroy of Muslims' property, and arguments ranged from invoking precedents like Abū Bakr's wars and other rational arguments or arguments from expediency. ${ }^{13}$

It is important to note that the punishment for apostasy as an offense committed by a group was never mentioned in the Qur ān, while a punishment for rebels, known as the bughāh, was mentioned (Qur ān 49: 9). Instead of considering Abū Bakr's rebels a paradigm case for the 'bughāh', the paradigm case for the bughāh according to Sunnī jurists were the Khawārij ("Seceders"), who rebelled against "Alī during his conflict with $\mathrm{Mu}^{\mathrm{c}} \overline{\mathrm{a}}$ wiya in the 650s and early 660s. Abu Bakr's wars against the apostates do not end up occupying a prominent position in juristic language about the punishment of apostasy as an offense by an individual. Sunnī jurists would mostly resort to Prophetic language in their treatment of the punishment of apostasy.

The statements attributed to the Prophet about executing those who 'change their religion' or 'those who change their religion and abandon their community' may have been in circulation from the mid-eighth

\footnotetext{
11 Ibid., 1075.

12 Ibid., 1078-79.

13 Ibid., 1088-94.
} 
century. The general language of these texts seems to address both the 'individual apostate' as well as apostasy as a collective form of rebellion. The lack of a general criterion of conversion from Islam, in these texts, remains their most significant quality. Around the same time these texts were circulating, Sunnī Muslim jurists began to debate an offense of apostasy committed by individuals and disagreed as to whether they should punish 'male' and 'female' apostates similarly or differently as well as other questions about who is an apostate and who is not. It will be upon Muslim jurists to develop a theory for apostasy identifying the offense that constitutes it and the authority that justifies punishing it.

Muslim jurists on the implications of apostasy in a socio-legal setting

In their treatment of the subject of apostasy, Sunnī Muslim jurists concerned themselves with the implications of being Muslim or nonMuslim, whether living in a Muslim society or outside of one. As Islamic law acknowledges religion's penetration into the intra-personal sphere, an individual's decision to abandon his/her Muslim identity affects his/ her actions prior to that decision. If this person acted as a Muslim and then was seen to have departed from his/her Muslim identity, his/her actions (marriage, will, contracts, etc.) must undergo re-evaluation. Muslims incur duties and merit rights by virtue of their commitment to the religion of Islam, while non-Muslims are seen to be outside of this circle of rights and responsibilities. A Muslim, for example, pays alms and taxes based on his/her income and property, while a non-Muslim pays a poll tax that was interpreted differently by different schools of law over the centuries (some saw it as a financial duty parallel to Muslims' giving of alms, some as a compensation for not serving in the army, etc.). A Muslim man can marry a Muslim woman, while a nonMuslim man cannot. A Muslim does not inherit from a non-Muslim relative, nor does a non-Muslim inherit from a Muslim.

There is also an inter-communal aspect to this question, since the jurisdiction of Islamic law is not restricted to a Muslim or non-Muslim living in a Muslim state. For example, what must be done with the property, inheritance, social and financial commitments of an ex-Muslim who emigrated to a non-Muslim community is addressed by Muslim jurists. Thus, in Islamic law, international order applies to the individual even if the individual is not a proper subject of international law. In sum, the Islamic juristic discourses on apostasy address personal identity of a political and religious nature as well as the larger questions of international order and community relations. The Uzbek Ḥanafĩ jurist Dabbūsī's (d. 1038) discussion of whether non-Muslims living in a Muslim com- 
munity must abide by aspects of Islamic law makes this point. ${ }^{14}$ One could also consult Zanjānī's (d. 1258) treatment of the same topic to see that an apostate represents a status that raises questions about what rights and duties can be attributed to an individual who was (but ceased to be) a Muslim. ${ }^{15}$

14 "For Abū Hanīfa [d. 767], protected people (ahl al-dhimma) are allowed to practice what they believe, and for his two students [Abū Yūsuf (d. 798) and Muhammad al-Shaybānī (d. 805)], they are not given a free pass to apply their law (la yutrakūn), and this has applications. One of these applications is that, when a dhimmi marries a dhimmiyya while she is in the middle of the ${ }^{c} i d d a$ [a period that must pass after the termination of her previous marriage and before she remarries, according to Islamic law], they are left alone (yutrakān); that is to say, they are allowed to remain married in Abū Hanīfa's view, while for the two students, these two people must be separated (yufarraq baynahumāa). Another one of these applications is that, if a dhimmi marries a close relative [when this would be incestuous in Islam], they should not be separated. That is, in Abū Hanīfa's view, they should be allowed to remain married unless they both seek a court decision by a Muslim judge, while for them [i.e., the two students], if only one of them resorts to a Muslim judge, the judge has the authority to separate them [annulling their marriage]. Yet another one of these [applications] is that, if a Magian/Manichean (majūs $\bar{\imath}$ ) married his mother and consummated the marriage and then converted to Islam, and was called an adulterer by another person, the latter must be punished for that, since - according to their [the Manichean] religion - they were allowed to do what they did (kāna yuqarrān ${ }^{c} a l \bar{a}$ dhălik). For the two students, the person who called the man an adulterer should not be punished for what he said. Another [application] is that, if a Manichean marries a female relative (whom he cannot marry under Islamic law), he owes her alimony, because the two [spouses] accept that relationship." Translated from Dabbūsī $T a^{D}$ sìs al-nazar (Cairo, n.d.), 13-14.

15 'The unbelievers are addressed by the obligation to perform the practices of Islam (furu $\bar{u}^{c}$ al-Islām), according to Shāfi ${ }^{\circ} \overline{1}$ (d. 820) (God be pleased with him), and this is also the view of the majority of the $\mathrm{Mu}^{\mathrm{c}}$ tazilites. He [Shāfi $\mathrm{i}^{\mathrm{i}}$ ] argued that based on general statements in the Qur ān, such as His saying (glorified is $\mathrm{He}$ ) [relating a dialogue among unbelievers and their punishers in Hell]: "They [Hell's guards] said, "What brought you to Hell (saqar)?" They [the unbelievers] replied, "We have not performed the prayers" (Qur ān 74: 4243). This indicates that they are punished for failing to perform the prayers. Also, His saying (glorified is He): "They do not call upon other gods with God, and whoever does that faces sins [usually understood to mean faces the consequences of sins], his punishment on the Day of Resurrection will be multiplied." (Qur`ān 25: 68). Also, His saying (glorified is He): "Woe to the unbelievers, who do not pay obligatory alms (zakāh)" (Qur ān 41: 6-7). Abū 
This is a point which Ghazālī makes repeatedly in his Fayșal altafriqa bayn al-islām wa-l-zandaqa (The distinction between Islam and zandaqa/unbelief), a treatise that represents a crucial moment in his juristic career. ${ }^{16}$ Ghazāli emphasized the legal ramifications of the ruling that somebody is a Muslim or not to indicate that he functions as a jurist as he attempts to provide an acceptable distinction between a heretic, who is still legally Muslim, and an unbeliever (or, for Ghazālī, a zindīq), who is not. His distinction, however, shows the philosopher side of him, as he attempts to explain that a heretic might deny 'one form of the existence' of the qualities of God, while acknowledging others, whereas the zindī $q$ denies what amounts to God's existence per se (e.g., holding that the world is co-eternal with God will amount to a denial of the very existence of God as God/Creator). Ghazālī's criterion fails to engage the legal discourse to consider a removal of any possible uncertainty between heresy and apostasy. It is important, at this point, to note that Ghazāli clearly understands that the implications of calling somebody an apostate are of practical significance for the law and affect that person's status in society.

A spectrum of deviations from Islamic norms

Sunnī Muslim juristic discourse on heresy and apostasy establishes a spectrum of 'deviations' from normative Islamic beliefs, one that includes doctrinal heresy and apostasy. To these must be added the position of 'original unbelief' or rejection of Islam without any history of

Hanīfa (God be pleased with him) and the majority of his followers held that the unbelievers are not addressed [by these duties]. They argue that, if the prayer, for example, became obligatory for the unbeliever, it would be obligatory either while he/she is an unbeliever or after. The first is impossible, because the prayer is not acceptable from an unbeliever while he/she is an unbeliever. The second is also impossible, because we all [Hanafĩ jurists as well as Shāficīs] hold that an unbeliever who embraces Islam is not required to perform the prayers he/she did not perform while an unbeliever. Applications branch out of this principle (yatafarra ${ }^{c}{ }^{c}$ ala hădhā al-aṣl masa $\bar{a}^{\circ} i l$ ). One of these is that an apostate (murtadd) who embraces Islam must perform the prayers he/she did not perform during his/her days of apostasy (ridda), and the same applies to unfulfilled fasting during the days of apostasy in our view. In this we disagree with him [Abū Hanīfa], since he considered the apostate the same as an unbeliever in that he/she is not bound by religious practices.' Mạ̣mūd ibn Aḥmad Zanjānī, (d. 1258), Takhrīj al-furūc ${ }^{c}$ alā al-uṣūl (Beirut and Damascus: $\mathrm{Mu}^{\circ}$ assasât alRisāla, 1987), 98-101. See also 327-28.

16 al-Ghazālī, Fayṣal al-tafriqa bayn al-islām wa-l-zandaqa, ed. Sulaymān Dunyā (Cairo: Dār Ihyyāō al-Kutub al- ${ }^{c}$ Arabiyya, 1961). 
believing in it. The different concepts of apostasy must be considered in light of the distinctions made between the different forms of deviation from the Islamic norms. Muslim jurists did not seem to attempt a decisive definition for apostasy in a way that prevents any flexibility in identifying an individual case of apostasy beyond doubt. This does not entail the impossibility of achieving such a goal, since Ghazālī attempted it in his Fayșal al-tafriqa, and since other (even more legally appropriate) criteria (such as subjecting the alleged apostate to a test) can be articulated easily. One possible explanation for this juristic silence is a sense of the inconsequentiality of individual apostates. The implication of this silence, however, is an inevitable degree of room for judicial discretion in deciding specific claims of apostasy.

Ghazāli himself partly agrees with the desirability of questioning the occurrence of apostasy in specific cases in his Iqtișād fi l-i ${ }^{c} t i q \bar{a} d$ (The golden mean regarding beliefs), but he refrains from reconciling that with his unqualified attacks on the philosophers and the leaders of the esoteric factions. One is left with the impression that the danger of a philosophy that questions the basis of Muslim creeds cannot be tolerated, and that Ghazāli could not find an excuse for these philosophers, since they seem to be deliberate in their effort to propagate their unbelief. Ghazāli qualifies his attacks on the esoteric factions, however, in a significant manner, as we shall see.

\section{The zandaqa and original unbelief}

The zindi $q$ was seen by most jurists as a class with an ambiguous relationship to apostasy rather than a substratum or synonym of apostasy, and the question of the $z i n d \bar{\imath} q$ has been posed in different terms at different times in Islamic legal and political history. Mālik (d. 795) understood the status of someone who becomes a zindī (yatazandaq) as someone who moves from one form of unbelief to another (kharaja min kufr ilā kufr). ${ }^{17}$ Mālik thus conceived of the zanādiqa as original unbelievers or scriptuaries (Jews or Christians) who later embraced other beliefs that are usually associated with believing in Manichaeism and with moral laxity. The possibility that an original Muslim would embrace these beliefs is thus not addressed in his outlook. Another minimizing of the $z i n d \bar{l} q$ was that he/she is someone with no religion who professes to be a Muslim. ${ }^{18}$ This is different from someone who

\footnotetext{
${ }^{17}$ Khalīl, Mukhtașar (Cairo, 1910; see n. 3), 6: 279

18 al-Kamāl ibn al-Humām al-Sīwāsī al-Hanafĩ (d. 1460), Sharh Fatḥ alQad̄̄r calā al-Hidāya of al-Marghīnānī (d. 1196) (Cairo, 1896), 4: 408. This is
} 
professes to be a Muslim while holding 'another religion'. Thus, a zindī $q$, in this sense, is not a crypto-Manichean or a crypto-Christian (or as al-Jāhị indicated someone with confused influence from Indian religions), but rather, someone with no specific convictions. One practical consequence of the distinction between an apostate and a zindī for those who decided to pass the death penalty on the latter is that the zindi $q$ is not expected to clarify his views or declare his repentance, since his beliefs are ambiguous to begin with. ${ }^{19}$

The conceptual distinction between an apostate and an unbeliever is not hard to make. The former is a person with a history of being a Muslim who abandons Islam, while the latter has not embraced Islam at all. Thus every apostate, as long as he or she is an apostate, is an unbeliever, but the opposite is not true. The unbeliever who is not an apostate can be a person with stable or changing beliefs that do not comply with acceptable Islamic creeds. Thus, an 'original unbeliever' is not addressed by the juristic discourses on apostasy.

In his Faḍa $\bar{a}^{\supset}$ h al-bātiniyya, Ghazālī reported three views on whether the battiniyya should be considered apostates, even if they do not seem to have any history of believing in Islam:

If it is said: why do you consider them (the esoteric sects) similar to the apostates? Whereas the apostates are those who accepted the correct religion and embraced it and then exited out of it, reverting and denying it[s truth], the former were never committed to the truth; rather they grew up believing in these [un-Islamic] creeds. Why do not you consider these (esoteric sects) similar to original unbelievers? To this we say: what we stated is clear in the case of those who embraced their religions and accepted them, believing in them after believing in their opposites or after not believing in them. As for those who grew up believing in these creeds as they heard them from their parents, then they are the scions of apostates, since their parents and the parents of their parents must be assumed to have believed in this religion after not believing in it, since this is not a religion that relies on the authority of a prophet and a revealed scripture, such as the beliefs of the Jews and the Christians. Rather, these are 'new heresies' (bida ${ }^{c}$ mustahdatha) [held] by the groups of the infidels and zanādiqa in these recent times. The case of the zindi $q$ is the same as that of the apostate; no distinctions can be made between them. But we must still inquire into the scions of the apostates. Some opined that they are apostates like their ancestors, such

an 8 volume, incomplete commentary on al-Hidāya, completed in two volumes (published in the same collection) by Shams al-Dīn Aḥmad, known as Qạdī Zāda (d. 1580), and entitled Takmilat sharh Fath al-Qadīr al-musammāh Natā̄ij al-afkār fí kashf al-rumūz wa-l-asrār.

${ }^{19}$ Khalīl, Mukhtașar (Cairo, 1910; see n. 3), 6: 286. 
as the children of unbelievers in battle or the children of the people of the dhimma. ${ }^{20}$ Based on this view, the child would be called upon to become a Muslim after becoming an adult, and if he/she rejects Islam, he/she would be killed, and neither jizya nor slavery would be accepted from him/her. Some said they are original unbelievers if they are born unbelievers. And if they continue to be the same after being adults, they can continue to pay the jizya or be slaves like their parents. Some said that they should be considered Muslims, since the apostate is held responsible for having even a possible relationship with Islam. Thus, if he/she reaches adulthood and is silent about his/her religion, he/she must be assumed a Muslim, until Islam is presented to him/her. If he/she accepts it explicitly, then he/she is a Muslim. If he/she continues to show signs of the unbelief of his/her parents, then he/she must be considered an apostate. This is what we believe should apply to the children of the battiniyya. ${ }^{21}$

Here Ghazālī endeavors to make a distinction between Jews and Christians, on the one hand, and the zanädiqa, on the other, since the former possess acknowledged scriptures, while the latter have come up with newly forged 'heresies'. Thus the zanädiqa do not deserve the protection given to Jews and Christians. But Ghazālī acknowledges that a strong argument would support considering the children of the zanadiqa original unbelievers rather than apostates. Thus he neutralizes the importance of his earlier argument, since only the passing of time is required to make the children of the zanädiqa unbelievers, unless these parents are exterminated. It is difficult to imagine that Ghazāli has entertained the hope that the zanädiqa would be obliterated if his policy of forcing their children to choose between Islam and being executed for their apostasy were adopted, since the zanadiqa seem to have persisted for a long time before he wrote his criterial treatise.

\section{Doctrinal heresy}

Sunnī Muslim juristic literature distinguishes between two types of heresy: doctrinal (qawliyya, literally "verbal") and action-based ( $f^{c}$ liyya). Those who fall short of being apostates are considered heretics in matters of doctrine. ${ }^{22}$

Among the heresies Ghazālī attacks are those of the $\mathrm{Mu}^{\mathrm{c}}$ tazilites, who are seen by many observers as the freethinkers of Islam, especially given their position on the attainability of moral knowledge through the un-

\footnotetext{
${ }^{20}$ These are two different groups, but they are similar in that the children follow the status of their parents.

21 al-Ghazālī, Faḍāịh al-bătiniyya, ed. ' Abd al-Raḥmān Badawī (Cairo, 1964), 158-59.

22 al-Ghazāīî, Fayșal al-tafriqa, 187, 195, and 197.
} 
aided intellect. But the $\mathrm{Mu}^{\mathrm{c}}$ tazilites, after all, were not as radical as some philosophers like Rāzī (d. 923), who seems to have believed that knowledge is attainable by the unaided intellect, whether or not revelation confirms that knowledge. ${ }^{23}$ The heresy of al-Warrāq and Ibn alRāwandī (ninth century) is of a different order. These, quite admittedly unclear figures, are reported to have adopted sophist methodology, at least in different stages in their career, showing signs of dissatisfaction with many assertions in Muslim doctrines, including the very idea of revelation and the inimitability of the Qur ${ }^{\circ} \bar{a} n .{ }^{24}$ Farābī (d. 950) may have been the first systematic skeptic whose concern with political philosophy led him to consider 'religion' a way for communities to organize themselves. Religions come out of philosophies, which may be advanced or primitive, but religions can be nothing but a metaphorical expression of the truth that philosophy attempts to acquire. ${ }^{25}$

Examples of doctrinal heresy or bidac taken from early Islamic theological and philosophical debates continue to be given by later jurists. These, according to Ibn al-Bazzāz al-Kardarī (d. 1424), include the belief that God possesses a body (though unlike other bodies), the belief that grave sinners $(f u s s \bar{a} q)$ are condemned to eternal residence in Hell, and the denial of punishment in the grave. ${ }^{26}$ These beliefs would contradict

${ }^{23}$ Muhsin Mahdi, Alfarabi and the Foundation of Islamic Political Philosophy (Chicago: University of Chicago Press, 2001), 51

${ }^{24}$ Sarah Stroumsa, 'The Blinding Emerald: Ibn al-Rāwandī's Kitāb alZumurrud', Journal of the American Oriental Society, 114/2 (1994): 181-84; David Thomas, Early Muslim Polemic against Christianity: Abū ${ }^{c} \bar{I} s \bar{a}$ alWarrāq's 'Against the Incarnation' (Cambridge: Cambridge University Press, 2002), 6-9. The Syrian poet Abū al- ${ }^{\mathrm{c}} \mathrm{Ala}{ }^{j}$ al-Ma ${ }^{\mathrm{c}}$ arrī (d. 1057) expressed another form of skepticism, amounting to a rejection of many of the claims of revelation and an assertion that 'power' imposes itself as the only reality in the world. $\mathrm{Ma}^{\mathrm{c}}$ arrī writes, 'These superstitions, sacred books and creeds / These cults and myths and other noxious weeds / So many lies are crowned in every age / While truth beneath the tyrant's heel still bleeds.' Abū al- ${ }^{\mathrm{c}} \mathrm{Ala} \overline{\mathrm{a}}^{\mathrm{j}}$ al-Ma $\mathrm{Marrī}^{\mathrm{c}}$, The Quatrains of $A b \bar{u}$ al- ${ }^{c} A l \bar{a}^{j}$, trans. A. Rīhān̄ī, (New York: Doubleday, 1903), 59.

25 In western philosophical traditions, skepticism, as a systematic position, is defined as either a commitment to the impossibility of knowledge or the inability to decide whether knowledge is possible (Pyrrhonian and academic skepticism; R. H. Popkin, The History of Scepticism from Erasmus to Descartes [New York: Harper Torchbooks, 1964], ix-xi). Fārābī seems to provide a different form of skepticism that neutralized the universal claims of religion without rejecting its partial validity for certain people.

${ }^{26}$ Ibn al-Bazzāz, al-Fatāwā al-Bazzāziyya (Cairo, 1892; reprint Beirut, 
the Māturīdī confession to which the author subscribes. However, when Ibn al-Bazzāz sets out to explain what should be done with doctrinal heretics, he emphasizes that if individuals find a person with such heretical views, they must 'guide him, and if he is a propagator of his heresy, they should prevent him from propagating it, and if they cannot, they should bring the matter before the judges so that they may expel such persons from the town. ${ }^{27}$ When it comes to apostasy, Ibn al-Bazzāz asserts that, if one can find different interpretations that confirm an alleged instance of apostasy and only one that raises doubt about it, then it must be assumed that apostasy did not take place, since this is not a matter that can be determined based on an accumulation of arguments. ${ }^{28}$

The structure of juristic discourses on apostasy

I shall now briefly compare four treatments of the subject of apostasy in Islamic intellectual history, those of Shāfi ${ }^{c} \overline{1}$, Ghazālī, Ibn Taymiyya (d. 1328) and Ibn ${ }^{c} \bar{A}$ bidīn (d. 1836). The first two of these four jurists have been treated elsewhere, where it is argued that Shäfi î̀'s concept of apostasy differs from Ghazālī's, as punishment of certain apostates (like the philosophers and zanādiqa Ghazālī considers non-Muslim) would be possible only under Ghazālī's concept of apostasy but not that of Shāfi ${ }^{c}{ }_{1}{ }^{29}$ One must note that Muslim jurists before Shăfi ${ }^{c} \overline{1}$ accepted the practice of istitäba (giving an opportunity to the alleged apostate to recant his/her offensive remarks or actions before being subjected to any punishment for apostasy), and it continues to appear in Sunnī juristic literature long after Ghazālī.

The third of these four jurists, the Syrian Hanbali jurist Ibn Taymiyya, presented a particularly rich treatment of the subject of apostasy, with examples of apostates of different stripes and an elaboration of their beliefs and practices as well as the implications of their apostasy. Ibn Taymiyya's tendency to elaborate (and occasionally digress) in his juristic writing is due at least in part to the fact that he conceived of his juristic task as an assessment of the mainstream Islamic juristic tradition as it reached him in the thirteenth and fourteenth centuries. Ibn Taymiyya is often critical of common juristic discourses and juxtaposes them with what he considers to be the path treaded by the first Muslim

1973), 6: 321. In 6 volumes, published on the margin of al-Fatāwa al-hindiyya, 6: 319 .

27 Ibid., 320.

${ }^{28}$ Ibid., 321.

${ }^{29}$ Griffel, 'Toleration and Exclusion', 339-54. 
generations or the salaf, i.e., those of the seventh and eighth centuries. Ibn Taymiyya's understanding of apostasy covers spiritual and political deviations. While recognizing intellectual freedom in principle, he hesitates to allow devotional passion and theological-political dissent that amounts to a rejection of the foundation of Sunnī Islamic thought. However Ibn Taymiyya remains loyal to the juristic position that apostasy is a grave matter, despite his insistence on a return to the ideals of the early generations of Islam as a 'pure moment' in Islamic history with defined orthodoxy and orthopraxy.

At the end of the eighteenth and beginning of the nineteenth century came Ibn ${ }^{\mathrm{C}} \overline{\mathrm{A}}$ bidīn, another Syrian, but Ḥanafī, jurist, who offered one of the last juristic treatments of the subject of apostasy before the interaction between Muslim and Western societies in the modern era reached a level of complexity that made it impossible for historians to single out Muslim juristic views that are unaffected by modern ideas and ideologies. Ibn ${ }^{\mathrm{C}} \overline{\mathrm{A}}$ bidīn is seen by his contemporaries as a master of Hanafĩ law and a mainstream jurist rather than a critic of the juristic tradition, such as Ibn Taymiyya. (Close reading of works like his often allows the reader to question sharp distinctions between participants in a legal tradition and its critics, but the fact remains that Ibn ' ${ }^{\mathrm{A}}$ bidīn's work has been considered by traditional scholars of law over the past two centuries to be a masterful presentation that comprehends previous doctrines on the subject.)

Ibn ${ }^{c} \bar{A}$ bidīn (d. 1836) hesitates both in ascribing apostasy and assigning capital punishment to alleged apostates. The category of apostasy, for Ibn ${ }^{\mathrm{C}} \overline{\mathrm{A}}$ bidīn, is almost a theoretical category, since any doubt about whether the alleged apostates have had a history of being Muslim and then reversed their identification with the Muslim community saves the alleged apostates from punishment. Ibn ' ${ }^{\mathrm{A}}$ bidīn's fears are directed toward the zanādiqa, i.e., those who pretend to be Muslims while functioning as a fifth column amidst a Muslim society, now seen as original unbelievers rather than apostates.

\section{Shä $\bar{i}^{c} \bar{\imath}(767-820)$ and apostasy}

Shāficīis $U m m$ is ultimately a source of law that accounts for many views that were expressed by Sunn̄̄ Muslim jurists in Iraq and Arabia in Shāfi ${ }^{1} \overline{1}$ 's generation and the generations preceding him. (My personal view that al-Umm was edited later than the first generation of the ninth century makes me also consider it a source of views that appeared after 820, Shāfi ‘̂̀'s death year; but this is another matter.) In Shāficī's discussion of apostasy, despite the fact that it appears fairly early in 
Islamic legal history, one finds that the main questions of apostasy have already been defined. It was clear that the individual crime of apostasy would concern Sunnī Muslim jurists more than collective rebellious apostasy. It was also clear that disagreement would occur about the rationale of the punishment and that the distinction between male and female apostates would also to be debated. More importantly, it was becoming clear that a crime of apostasy would be defined only in general terms, awaiting judicial discretion for its application in specific cases. The Sunnī juristic discourses on apostasy would continue to provide modifications to some of the specific consequences relating to the status of apostates, as well as new and more nuanced positions concerning specific questions on the practical consequences of apostasy.

In al-Umm, Shăfi ${ }^{\mathrm{c}} \overline{1}$ argues that the condition of apostasy consists in a clear expression of a doctrine that is irreconcilable with Islamic beliefs as opposed to holding these beliefs. ${ }^{30}$ Using a variety of arguments from the Qur ${ }^{\circ} \bar{a}$ as well as precedents from the first generation of Muslims, he establishes that even if one suspects that an alleged non-Muslim uses the declaration of Islam to gain the benefits of being a Muslim, he/she must be granted the status of being Muslim. ${ }^{31}$ An alleged apostate needs only to profess to be a Muslim, and even if evidence supports the allegation of his apostasy repeatedly, only a discretionary punishment may be instituted, rather than a condemnation to apostasy. ${ }^{32}$ Shäfi ${ }^{\mathrm{c}} \overline{1}$ rejects the argument that an alleged apostate who embraces esoteric beliefs of zandaqa must be punished despite his/her declaration of being a Muslim (which makes it clear that Ghazāli three hundred years later was not the first to espouse this view), and he cites agreement with his view on the part of the jurists of Mecca, Madīna and the East (mashriqiyyūn). ${ }^{33}$

Ghazālì (1068-1111) and apostasy

Ghazālī's verdict on philosophers (declared in his Tahäfut or The Incoherence of the Philosophers) was that they must be considered 'unbelievers' if they hold any of three views: 1) the eternity of the world, 2) God's ignorance of the particulars of the world, or 3) that bodies are not resurrected in the afterlife. In his Fayșal al-tafriqa bayn al-islām wa-

\footnotetext{
${ }^{30}$ Muḥammad ibn Idrīs al-Shāfi ${ }^{c} \overline{1}, a l-U m m$, ed. Muḥammad Zuhrī al-Najjār (Cairo: Maktabat al-Kulliyyāt al-Azhariyya, 1961), 6: 156-57. In 8 volumes.

${ }^{31}$ Ibid., 156 for arguments from the Qur ān and 167 for a precedent from 'Umar's time.

32 Ibid., 158.

33 Ibid., 164
} 
l-zandaqa, Ghazālī asserts that different interpretations of 'existence' and the 'existent' are expressed by different theologians whose Islam is not to be questioned. ${ }^{34}$ Ghazāli conceived of three grades of deviation from Muslim beliefs. ${ }^{35}$ First is the view of the $\mathrm{Mu}^{\mathrm{c}}$ tazilites, who apply their rational arguments to interpret the revelation in what he considers unacceptable ways. Second is a stage between the first and the third one, which is the first grade of zandaqa, such as the belief that the Prophet would have his followers believe things like the resurrection of the body in the afterlife without these being literally true (note Farābī's thesis that religious doctrines are metaphorical expressions of philosophical truth). The third and last stage is that of denial of Islamic beliefs, which is the position ascribed to the philosophers and the zanādiqa.

In his Faḍ $\bar{a}^{\supset} i h$ al-bātiniyya, Ghazālī produces a more elaborate juristic treatment of the subject of apostasy. In this text, he addresses the distinctions between 'leaders' of apostates and 'followers', who may have been duped into holding the incorrect creeds the former taught. To these followers, only heresy can be attributed, since they are laypeople, even if they believe that the majority of Muslims are indeed usurpers of rightful power (ahl baghy) who disagree with the rightful leader of the Muslim community. ${ }^{36}$ Even regarding those who believe that the first two leaders of the Muslim community (Abū Bakr and ${ }^{~} \mathrm{Umar}$ ) were grave sinners, all that can be proven in their case is heresy (thus, $S^{-} \overline{1}^{c} \overline{1}$ commoners are only heretics). ${ }^{37}$

Ghazāli applies the same standard to the commoners among the zanādiqa he attacks consistently. It is not true that Ghazâli absolutely rejects the repentance of these groups; he divides them into three groups. The first group includes those who reject their previous beliefs without war. These should be forgiven, since people often realize the faults of their ways and repent without fear of force. The second group includes those who repent to avoid death. These should also be forgiven, as long as it is not feared that they will continue to spread their faulty ideas later, that is, become preachers (man lam yakun mutarashshihan li-l-dac wa). The third group includes those who do not believe in the correctness of the view they seem to espouse but use these views to seek a position of leadership. This group may not be forgiven right away nor punished right away, but the political leader must make a decision about them on a

\footnotetext{
34 al-Ghazālī, Fayṣal al-tafriqa, 175-78

35 Ibid., 192.

36 Ghazālī, Faḍāo iḥ al-bātiniyya, 146-47.

37 Ibid., 147.
} 
case-by-case basis. ${ }^{38}$

Ibn Taymiyya (1263-1328) and apostasy

Five years after the Mongols had sacked Baghdad in 1258, Ahmad ibn ${ }^{\mathrm{c}}$ Abd al-Ḥalīm Ibn Taymiyya was born in Harrān, Syria. Many commentators on his life have made Ibn Taymiyya's milieu a 'sufficient reason' for the sternness for which he came to be known. At any rate, it is indisputable that Ibn Taymiyya was unique in his disenchantment with the political authorities, the leaders of popular spiritual culture, and the intelligentsia. Ibn Taymiyya's dissenting position, however, was not (for the most part) an incentive for him to accept dissent. Ibn Taymiyya rarely cheers for dissenting voices, even though he was considered one in his context (and even later in many theological and juristic circles up to the modern era). Ibn Taymiyya, however, was anything but an exception in limiting dissent in religious matters to academic circles, as we shall see presently.

Ibn Taymiyya's treatment of the subject of apostasy in volume 35 of his responsa or Fatāwa ${ }^{39}$ is particularly rich, reflecting how he conceived of his juristic work as an assessment of the broad range of juristic production during the centuries that separate him from the first Muslim generations (the salaf, i.e., the seventh and eighth centuries). Ibn Taymiyya may have been a revisionist in his treatment of the laws of rebellion (ahkām al-bughāh), where he condemns both political rebellion and the legitimization of combating rebels by war. ${ }^{40}$ But in the matter of apostasy, his treatment does not deviate from the common position of acknowledging the difficulty of determining specific cases of apostasy. Ibn Taymiyya's distinctiveness was in another area of his juristic discourse. He seems to endorse 'religious war' against deviant sects, such as the Isma $\bar{a}^{c} \bar{l} l \bar{i} s$, while remaining conservative in assigning the label of apostasy to individuals.

Ibn Taymiyya asserts that declaring someone an apostate on the basis of that person's opinion is unacceptable ${ }^{41}$. He further warns against encouraging laypeople to declare scholars infidels because of these scholars' views. An example given is Ghazâlī's view that the Prophet

\footnotetext{
${ }^{38}$ Ibid., $160-63$.

${ }^{39}$ Ibn Taymiyya, Majmū $\bar{u}^{c}$ al-fatāwa $\bar{a}$, ed. 'Abd al-Raḥmān al-Najdī and Muḥammad al-Najdī (Riyāọ: Dār ${ }^{\mathrm{c}} \bar{A} l a m$ al-Kutub, 1961-67), 35: 99-207.

${ }^{40}$ Khaled Abou El Fadl, Rebellion and Violence in Islamic Law, (Cambridge, 2001), 271-73.

${ }^{41}$ Ibn Taymiyya, Majmū $\bar{u}^{c}$ al-Fatāwā, 35: 100-102.
} 
Muhammad made a mistake in the famous story of $T a^{3} b \bar{r}$. The Prophet noticed that the people of Medina applied a technique in pollination for palm-trees heretofore unfamiliar to him where the farmers hit the branches of the trees against one another to improve their capacity for pollination. For some reason the Prophet asked the farmers to refrain from this practice, and as they followed his command, the harvest was apparently badly hurt. The reason the farmers followed the Prophet's orders was their belief that he spoke on the basis of divine revelation, an impression he himself contradicted. The Prophet is reported to have said, 'You are more knowledgeable about matters pertaining to your daily life.' Ghazālī, not unlike other theologians, infers from this story the fallibility of the Prophet in worldly matters. Ibn Taymiyya thus reprimands those who indulge in attacking Ghazālī by pointing to the fact that his opinion is not an abberation (indeed Ghazālī's view was also that of other theologians who stated that the Prophet made mistakes, just like everyone, but that revelation did not leave his mistakes uncorrected, while others' mistakes remain uncorrected, as none of them can truthfully claim to be in contact with that source of revelation). Ibn Taymiyya here acknowledges a scholar's right to provide an independent opinion (ijtiha $\bar{d}$ ) based on competence, while none the less reserving much space for intellectual dissent. He could not allow the general public any similar right to offer their own opinion without the prerequisite competence.

Hallāj's (d. 922) ecstatic apostasy was not accepted by Ibn Taymiyya, who shows no sorrow for Hallāj's execution..$^{42}$ Hallāj's case is a famous case of 'religious passion,' but his failure to refrain from using expressions that made others consider him an unbeliever (as he seemed to confuse himself with the Creator Himself) left him unexcused in Ibn Taymiyya's eyes. Why is Hallāj's ecstatic longing for the Divine, which made him experience 'annihilation' in God, less honorable than theological-juristic theory that may amount to disrespect for the Prophet of Islam? For Ibn Taymiyya, the need to express religious passion is much less important that the need to explicate religious doctrines or contribute to a juristic debate. Hallajj did not need to teach others his ideas about how to worship God through total annihilation of the self in the Divine, since this (annihilation) can mean different things to different people and clearly diverges from the straightforward language of Scripture that distinguishes between the Divine and humans.

Just as expressing personal passion for the Divine might lead to abandoning the correct faith, so also religious-political sectarian teachings

42 Ibid., 108-19. 
that purport to be part of Muslim doctrine end up creating a parallel system of beliefs that diverges clearly from Islamic 'orthodox' beliefs. Ibn Taymiyya condemns Ismā $\bar{a}^{1} 1 \overline{1}$ imām-caliphs such as the Fatimid ruler al$\mathrm{Mu}^{\mathrm{c}}$ izz (d. 975). ${ }^{43}$ The claim of al-Mucizz to 'hidden' knowledge amounts, for Ibn Taymiyya, to abandoning the correct Islamic beliefs for personal preference. Ibn Taymiyya also condemns the Druze, ${ }^{44}$ whose origin can be traced to another Fātimid ruler, al-Hākim (d. 1021). A teacher by the name of ${ }^{\mathfrak{c}}$ Abd Allāh or Muhammad al-Darazī (d. 1020) preached in Syria that al-Hākim was the end of a line of nobles who can be seen as an incarnation of God, which line begins with ${ }^{\mathrm{c}} \mathrm{Al} \overline{\mathrm{i}}$ ibn Abī Țālib (d. 661), Muhammad's cousin and son-in-law (sources tell conflicting stories about al-Hākim's approval of Darazī’s teaching). For Ibn Taymiyya, the Druze are already far removed from correct Muslim doctrine and cannot be seen as Muslims. (Today the Druze would refer to themselves simply as monotheists [muwahhidiunn] rather than Muslims.)

Ibn Taymiyya thus expresses a measure of intolerance about political and spiritual dissent, while defending the right of scholars to dissent as part of their theological and legal deliberation. However, for Ibn Taymiyya, mere faith in times of 'religious indifference' is sufficient to guarantee salvation from Hell, ${ }^{45}$ and anyone with even a small measure of faith is guaranteed escape from perpetual residence in Hellfire, but not from proportionate punishment in Hell for bad deeds, such as theft and fornication. ${ }^{46}$ (Ibn Taymiyya also cautions that no one should believe that the mere profession of the correct faith guarantees entry into Paradise). ${ }^{47}$ Furthermore, inadvertent errors about what is correct Islamic doctrine (a position into which even the Prophet's Companions occasionally fell) are forgivable. ${ }^{48}$ Ibn Taymiyya's tolerance for the ignorance of well-intentioned individuals stands in contradistinction to his view of 'willful' deviation from the straight path of Islam.

Ibn ${ }^{c} \bar{A}$ bidīn (1783-1836) and apostasy

In Ibn 'Ābidīn's chapter on apostasy in his commentary Radd al$m u h t a \bar{a} r^{49}$ the possible punishment of the apostate by death is treated with

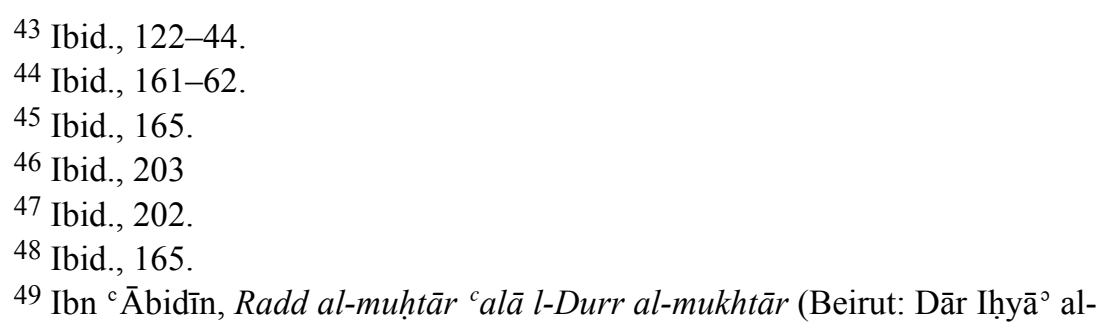


ambivalence, appearing mostly in assertions of the difficulty and awesomeness of the decision to punish someone by death because of a position he/she may or may not have intended to take. Ibn ${ }^{\mathrm{c}} \overline{\mathrm{A}}$ bidīn establishes the principle that one must avoid declaring someone a non-Muslim based on this person's utterances, since these can be interpreted differently by different audiences, and if one can interpret the utterances in a manner consistent with the person's Islamic identity, one must do so. ${ }^{50}$ Ibn 'Ābidīn's hesitation to punish apostates by death, however, finds an exception in the case of those who are accustomed to claiming they are Muslims, while hiding disrespect for the doctrines of Islam and violating them..$^{51}$

If these are the zanādiqa, then Ghazālì's assertion that secret apostates are punishable by death has triumphed. But Ibn 'Ābidīn's examples raise doubt about this possibility. The Druze are a clear example of those who claim to be Muslim while hiding unbelief. For Ibn ${ }^{\mathrm{c}} \overline{\mathrm{A}}$ bidīn, the Druze are neither Muslims nor apostates. ${ }^{52}$ Their status more closely resembles that of neighboring non-Muslim communities (the Druze often lived as nomads in mountainous areas and rarely mingled with urban or suburban populations). Furthermore, despite his quoting Ghazālī’s harsh language on the zanādiqa and even Sūfîs who share disrespect for Islamic practices while paying lip-service to them, Ibn ${ }^{\mathrm{c}} \overline{\mathrm{A}}$ bidīn asserts that 'there is no doubt that the apostate is one thing, and the zindi $q$ is another. ${ }^{53}$ Not only that, Ibn ${ }^{\mathrm{c}} \overline{\mathrm{A}}$ bidīn accepts a de facto coexistence of the Druze among Muslims with their (peculiar) partial identification with the Muslim faith. According to Ibn ${ }^{\mathrm{c}} \overline{\mathrm{A}}$ bidīn, a Druze court decision is binding only for its own people. ${ }^{54}$

When it comes to the Wahhābīs, the followers of Muhammad ibn ${ }^{c} \mathrm{Abd}$

Turāth al-Arabī, 1987), 3: 283-308. The commentary of Ibn ${ }^{\mathrm{c}} \overline{\mathrm{A}}$ bidīn (also known as Hāshiyat Ibn ${ }^{c} \bar{A}$ bidīn) on the text of al-Durr al-mukhtār by al-Hașkafī (d. 1677) is seen as an encyclopedia of late Hanafì law. References are to the reprinted Beirut edition of 1987.

50 Ibid., 3: 289.

51 Ibid., 269

52 Ibid., 297-98.

53 Ibid., 297 and 293. Ibn ${ }^{\mathrm{c}} \mathrm{A}$ bidīn developed a habit of quoting from sources with no endorsement or criticism, or with implicit endorsement, while qualifying aspects of what he quotes in other places. Among those whom he quotes is Ibn Taymiyya, especially his harsh language on those who apostatize and blaspheme the Prophet Muhammad; see 3: 279.

54 Ibid., 4: 299 
al-Wahhāb (1699-1792), Ibn ' ${ }^{\mathrm{A}}$ bidīn considers them the 'Khawārij' ("Seceders") of his time, ${ }^{55}$ as they rejected the acceptable leaders of the Muslim community in their time and declared their opponents nonMuslims. Wahhābism remained for a time an underground movement, but became politically active towards the end of the eighteenth century. The Wahhābīs attacked the Ottoman-appointed prince of Mecca in 1791 for the first time and were able to enter the city in 1803 to disseminate their beliefs. The city was ultimately surrendered to them in 1805 . Ibn ${ }^{\mathrm{c}} \overline{\mathrm{A}}$ bidīn does not consider their actions a sufficient basis for considering Wahhābīs non-Muslims. In identifying what was wrong with both Wahhābī and Khārijite religious-political aberration in their Muslim communities, Ibn ${ }^{\mathrm{c}} \overline{\mathrm{A}} \mathrm{bid} \overline{\mathrm{n}} \mathrm{ignores}$ the fact that ${ }^{\mathrm{c}} \mathrm{Al} \overline{\mathrm{i}}$ 's opponents include $\mathrm{Mu}^{\mathrm{c}} \overline{\mathrm{a}}$ wiya's followers, who began in the opposition and ended up being the mainstream of the Muslim community since the seventh century (the Sunnī Muslims).

Ibn 'Ā bidīn's interest in the applications of one's status as Muslim or non-Muslim is paramount. He classifies an apostate's actions as 1) actions that must be validated, 2) actions that must be invalidated, 3) actions whose validation hinges on the apostate's recovery of his/her Islamic faith (some disagreement among Hanafi jurists with regard to some actions, with some of them considering these actions valid and some considering them contingent on the apostate's recovery of his/her Islamic faith), and he deals with examples of these. ${ }^{56}$

\section{Doubt about claims of apostasy}

Sunnī Muslim jurists have struggled to identify examples of apostasy that cannot be debated. In addition to the aforementioned requirement of a demonstrated belief and acceptance to carry out Islamic religious practices before debating an offense of apostasy, ${ }^{57}$ it remained to be established that the action purporting to be an act of apostasy was unambiguous.

It is clear that groups of Muslims were accused of being apostates from time to time. The behavior of Muslims living among a majority of non-Muslims, for example, has stirred accusations of this nature. When Muslims lived in areas that are inhabited by many non-Muslims, the behavior of these Muslims could be mistaken for an expression of apostasy. Accusing these Muslims of being apostates was condemned by Ibn

\footnotetext{
55 Ibid., 3: 309.

56 Ibid., 301.

57 al-Hạțāā, Mawāhib al-Jalīl , 6: 279.
} 
al-Bazzāz in no uncertain terms. ${ }^{58}$ Some of the examples of ambiguity of the position of the apostate indicate Muslim jurists' awareness that common parlance includes expressions that are not meant to be a rejection of the Islamic teachings or the authority of the Prophet of Islam, but are only rhetorical expressions of the rejections of suggestions made by others. Thus, if somebody says 'I would not do such and such (which is known to be a norm instituted by the Prophet), even if the Prophet came to me and asked me to do it,' this cannot establish apostasy. ${ }^{59}$ Furthermore, Muslim jurists also accepted another caveat. When regular people accuse others of apostasy, they may have misinterpreted their behavior for disrespect of the Islamic teachings or authority, when their behavior could be interpreted in a different way. Thus, when somebody laughs at a statement expressing unbelief or ridiculing some of the Islamic doctrines, a jurist must inquire as to whether this was a natural reaction to attempt to make people laugh. ${ }^{60}$

\section{Ghazālì's contribution}

The disagreement about who is an apostate seems to have reached a degree of maturity and complexity before Ghazālī came to the juristic scene. But another important fact was that Muslim jurists did not need to argue that a group of rebels are apostates to argue for the legitimacy of combating them. The laws on the bughāh or rebels had been developed into a theory that allows the political authorities to punish rebels without considering them unbelievers. Further, Shāfi ${ }^{\mathrm{c}} \overline{1}$ 's istitäba (or the demand to repent) was not only applied to apostates; in fact, Mālik applied it to rebels who were admittedly Muslims. Mālik also believed that these rebels must be attacked militarily (like the apostates of Abū Bakr's time) not as a punishment for their unbelief, but in order to 'neutralize their corruptive influence' (daf'an li-fasādihim lā li-kufrihim) ${ }^{61}$

Ghazālī, however, attempted a twofold contribution to the juristic discourse on apostasy. First was his association of unbelief (kufr) with zandaqa (a matter contested before and after he wrote), and second was

\footnotetext{
58 Ibn al-Bazzāz, al-Fatāwā al-Bazzāziyya, 6: 321.

59 Sulaymān ibn 'Umar/Muhammad al-Bujayrimī (d. 1806), al-Tajrīd li-naf' al- ${ }^{c} a b \bar{d}$ (gloss on Zakariyyā al-Anșārī's [d. 1520] commentary on Manhaj alTullāb, his own abbreviation of al-Nawawī’s [d. 1278] Minhāj al-țālibīn) (Cairo, 1950), 4: 205. In 4 volumes.

60 al-Fatāwā al-Bazzāziyya, 6: 311.

61 al-Kamāl ibn al-Humām al-Sīwāsī al-Ḥanafī (d. 1460), Sharḥ Fatḥ alQadīr , 4: 408.
} 
his attempt to distinguish apostasy from mere heresy. Ghazālī, indeed, was aware of what he was doing; he knew that if he succeeded in including both philosophers and those who hold esoteric beliefs among the apostates, his attacks on both the philosophers and the esoteric factions would be most successful. Ghazālī also attempted to provide clear definitions that distinguish doctrinal heresy from apostasy in his Fayṣal. However, Ghazālī ultimately failed on both counts. He failed in changing the tenor of the juristic discourse, and the zanaddiqa continued to be an elusive term used differently by different jurists. ${ }^{62}$ The elasticity of the concepts of apostasy and heresy survived despite his Fayșal.

Ghazâlī's double attack on philosophers and esoteric factions betrays an awareness of the influence philosophers like Farābī (d. 950) had (inadvertently) exercised on the formulation of Ismân ${ }^{\mathrm{c}} 1 \overline{1}$ cosmology. ${ }^{63} \mathrm{In}$ fact, he points out a potential connection between the esoteric movements (on the one hand) and Dualism/Manichaeism (al-Thanawiyya) and philosophers (on the other). ${ }^{64}$ But this adds no clarification to the position of either the esoteric or the philosophical 'deviant' with respect to the gradations of heresy and apostasy. Ghazālī's examples of what constitutes unbelief have certainly penetrated into juristic writings about apostasy (for example, jurists begin to state that those who believe that the world may have existed eternally are unbelievers). However, in the same juristic works one reads that an apostate who reverts to Islam and then back into unbelief and so on must only be punished for his vacillation (as a crime of $t a^{c} z \bar{\imath} r$ ). ${ }^{65}$ Ironically, Ghazāli influenced the juristic discourse on apostasy in a manner he himself may not have intended. Ghazālî̀'s attack on the Ismâ ${ }^{c} \overline{1} l \overline{1}$ s paved the way for a return to Ibn Hanbal's (d. 856) anti-Shī ${ }^{\complement} \overline{1}$ sentiments, further developed by Ibn Taymiyya in the fourteenth century.

\section{Conclusion}

The application of a punishment of apostasy to specific individuals before a Sunnī court of law included a large measure of judicial discretion. The Sunnī judge had to undo any possible conflation between a claim of apostasy and a claim of doctrinal heresy in the case before

\footnotetext{
62 This conclusion is also corroborated by a survey of the use of the word outside juristic writings. See F. C. de Blois, 'Zindīk' in $E I^{2}, 11: 510-13$.

${ }^{63}$ Wilferd Madelung, Religious Trends in Early Islamic Iran, Columbia Lectures on Iranian Studies 4 (Albany: Bibliotheca Persica, 1988), 101.

${ }^{64}$ Ghazālī, Faḍ̄à ih al-bāținiyya, 4 and 9.

65 al-Ḥațāāb, Mawāhib al-Jalīl, 6: 282.
} 
him. The Sunnī judge also had to decide whether there was any question that the alleged apostate might be an original unbeliever who never fully embraced Islam. These two issues apply to individual apostates. As for declaring war as a punishment for apostasy, one must consider another set of facts, notably the availability of a punishment for political rebels who were considered Muslims. The collective punishment of apostates by war remain the least sufficiently theorized aspect of the Islamic juristic discourses on apostasy, a situation that obtained before and after Ghazālī, which allowed for a wider use of the laws on Muslim rebels (bughāh) by Muslim rulers. This fact will be part of the explanation for the fact that a frequent application of the laws of apostasy was not needed.

I must now address a natural objection to the argument I have developed here: the argument seems either to deny or to play down any change in the discussion of apostasy in Sunnī Islamic law. Fear of finding general themes shared by Muslim jurists, at least after the first two or three Islamic centuries, is understandable, since this seems to take us in the direction of essentializing aspects of Islamic law and Islam itself. In a previous study, I suggested that, within the same juristic discourse, one can identify layers of 'structural interrelations' between theoretical reasoning and practical legal decisions, which allow for the modification of legal theory and practice without demolishing some of the basic structure taken from the legal theory discourse. ${ }^{66}$ To apply this notion to the apostasy case, the theories of what apostasy is has evolved out of an implicit assumption about the spectrum of deviations from Islamic norms, while different positions in relation to that spectrum could be debated. Of course, a modification of the theoretical framework is always possible, but jurists must feel a need for that in order to carry it out. In a study of the historical evolution of these structures, any change in the level of theory or practice must be demonstrated rather than assumed. In the case of apostasy, the three categories of 'doctrinal heresy,' 'apostasy,' and 'original unbelief' had been identified and debated even before Shăfi ${ }^{c} \overline{1}$. Ghazāli could have debated the adequacy of the structure the theory provides or the position of major categories falling into that structure. But he chose to debate the uncertainty inherent in the concept of apostasy because of its conflation with doctrinal heresy. For their part, Sunnī juristic discourses continued to insist on the difficulty of resolving the distinction conceptually, given their concern with how this will apply in specific cases.

\footnotetext{
${ }^{66}$ Ahmad Atif Ahmad, Structural Interrelations of Theory and Practice in Islamic Law: A Study of Six Works of Islamic Jurisprudence (Leiden: Brill, 2006).
} 